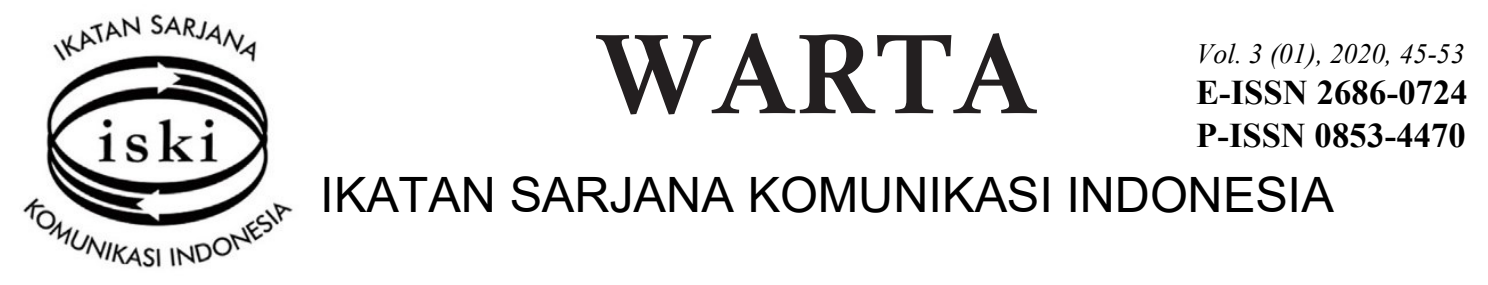

\title{
Presentasi Diri Orang dengan HIV/AIDS (ODHA) di Kota Pekanbaru - Riau
}

http://dx.doi.org/10.25008/wartaiski.v3i01.50

\author{
Genny Gustina Sari ${ }^{1 *}$, Welly Wirman ${ }^{2}$, Marisando Simarmata ${ }^{3}$ \\ 1,2,3 Jurusan Ilmu Komunikasi FISIP Universitas Riau \\ Simpang Baru, Tampan, Pekanbaru 28293 - Indonesia \\ *e-mail korespondensi: genny.gustina@1ecturer.unri.ac.id
}

Submitted: 13/04/2020, Revised: 05/05/2020, Accepted: 03/06/2020

Accredited by Kemristekdikti No. 30/E/KPT/2019

\begin{abstract}
People living with HIV-AIDS (ODHA) often face rejection from the community. They often hide their identity as HIV-AIDS carriers to make them acceptable to their environment. Consequently, they have to control their behavior and attitudes when interacting in the community. This study aims to see the Self-Presentation of People Living with HIV-AIDS (ODHA) in Pekanbaru using Dramaturgi's theory. The results of this study show that the front stage of ODHA consists of a setting (place), in that when they are in the public room, they refuse topics of discussion about health, tell lies and reject an offer to accompany them to the hospital. In their manner and attitude, they are reluctant to shake hands, stay cool to others, exercise, and never offer food to anyone. They are neat and clean in appearance, and always wear a mask when traveling. The back stage of ODHA is that they behave openly, and gather with their community. ODHA also have manner (style) and attitude of going to the hospital and taking medicine secretly. They feel happy, excited, more open and freer when getting together with fellow ODHA.
\end{abstract}

Keywords: Dramaturgi's theory; HIV-AIDS; Living with AIDS ODHA; Self Presentation

\begin{abstract}
Abstrak
Orang yang hidup dengan HIV-AIDS (ODHA) sering mendapatkan penolakan dari masyarakat sehingga sering menyembunyikan identitasnya sebagai pengidap HIV-AIDS agar mereka diterima di lingkungannya. Hal ini menuntut ODHA untuk mengatur perilaku dan sikapnya ketika berinteraksi di masyarakat. Penelitian ini bertujuan untuk mengetahui Presentasi Diri Orang Dengan HIV-AIDS (ODHA) di Kota Pekanbaru dengan menggunakan teori Dramaturgi. Hasil dalam penelitian ini menunjukkan bahwa panggung depan ODHA terdiri dari setting (tempat) yaitu saat berada di ruang publik mereka mengelak topik pembicaraan tentang kesehatan, berbohong dan tidak mau ditemani ke rumah sakit. Untuk manner dan sikap, mereka enggan untuk bersalaman, bersikap dingin kepada orang lain, berolahraga, dan tidak pernah menawarkan makanan kepada siapapun. Untuk appearance ODHA berpenampilan rapi dan bersih, saat bepergian selalu menggunakan masker. Panggung belakang (back stage) ODHA berperilaku terbuka. Mereka berkumpul bersama dengan komunitasnya. Untuk manner (gaya) dan sikap ODHA ke rumah sakit dan meminum obat secara sembunyi-sembunyi. Merasa bahagia dan bersemangat serta lebih terbuka dan leluasa jika kumpul bersama sesama ODHA.
\end{abstract}

Kata Kunci: Hidup dengan AIDS; HIV-AIDS; ODHA, presentasi diri; teori dramaturgi

PENDAHULUAN

Human immunodeficiency virus (HIV) menurut Crish W. Green adalah virus yang menyerang sistem kekebalan tubuh manusia sehingga kemampuan tubuh melawan bakteri dan virus menjadi lemah. Akibatnya, para penderita HIV rentan terserang berbagai macam penyakit. Gejala penyakit itu antara lain demam, batuk, diare terus-menerus hingga menurunnya berat secara drastis. 
Warta Ikatan Sarjana Komunikasi Indonesia e-ISSN: 2686-0724 - p-ISSN: 0853-4470 - Vol. 3, No. 01 (2020), pp. 45-52

Kumpulan gejala penyakit akibat lemahnya sistim kekebalan tubuh itu disebut AIDS atau Acuired Immune Deficiency Syndrome (Maengkom, Kaunang, \& Korompis, 2017). HIV ditularkan melalui cairan tubuh seperti darah, air mani, cairan vagina dan air susu ibu. Penularan HIV tidak terjadi melalui kontak fisik seperti bersalaman atau berpelukan.

Penularan HIV dapat terjadi melalui transfusi darah, hubungan seksual, penggunaan jarum suntik yang telah terkontaminasi HIV AIDS (Green, 2016:5-7). Sebutan untuk pasien HIV disebut ODHIV (orang dengan HIV). Sebutan itu ditujukan kepada orang yang terinfeksi HIV tetapi belum sampai ke tahap AIDS. Jika sudah mengidap AIDS maka pasien itu disebut Orang dengan HIV/AIDS atau ODHA (Maengkom et al., 2017).

Data United Nations Program on HIV and AIDS menunjukkan, tahun 2018 tercatat 1.7 juta jiwa terinfeksi HIV di seluruh dunia, sedangkan penderita HIV-AIDS mencapai 37.9 juta jiwa dengan 770 ribu meninggal dunia (https://www.unaids.org/en). Di kawasan Asia Pasifik penderita HIV AIDS tercatat 5.2 juta jiwa. Indonesia menduduki peringkat ketiga dengan pengidap HIV AIDS sebanyak 620.000 jiwa. Jika dikelompokkan berdasarkan latar belakang, pengidap HIV AIDS tersebut tahun 2017 adalah sebagai berikut (Tabel 1):

Tabel 1. Kategori Pengidap HIV AIDS Berdasarkan Latar Belakang

\begin{tabular}{clc}
\hline No & Kategori & Persentase \\
\hline 1 & Pekerja seks komersil & 5,3 \\
2 & Homoseksual & 25,8 \\
3 & Transgender & 24,8 \\
4 & Tahanan/narapidana & 2,6 \\
5 & Pengguna narkoba (suntik) & 28,76 \\
6 & Faktor-faktor lainnya & 12,74 \\
\hline & Total & 100 \\
\hline
\end{tabular}

Pengguna narkoba melalui jarum suntik dan homoseksual merupakan penyumbang terbesar dari total keseluruhan jumlah pengidap HIV di Indonesia, dan transgender berada di urutan ketiga. Penyebaran HIV itu bisa ditekan jika pemerintah dan masyarakat mengawasi para pengguna narkoba, pelaku homoseksual dan transgender. Di Kota Pekanbaru, berdasarkan data Dinas Kesehatan Kota pada Juni 2018 tercatat 1.476 pengidap HIV dan 1.437 pengidap AIDS.

Suzana Murni, dkk (2007:42) dalam penelitiannya menyatakan orang dengan HIV/AIDS mencoba memperbaiki tingkah laku mereka, tetapi sikap dan stigma negatif masyarakat terhadap mereka menjadi kendala, padahal stigma negatif dari masyarakat dapat merubah konsep diri ODHA (Wahyu, Taufik, \& Ilyas, 2012). Kenyataan di lapangan, pihak yang memberikan stigma negatif ke ODHA empat kali lebih besar dibandingkan yang lainnya justru berasal dari keluarga.

Sikap keluarga dan persepsi masyarakat terbukti berpengaruh pada munculnya stigma negatif yang lebih luas di masyarakat (Shaluhiyah, Musthofa, \& Widjanarko, 2014). Stigma negatif itu berasal dari anggapan bahwa HIV/AIDS merupakan hukuman dari Tuhan akibat perbuatan mereka. Masyarakat menilai ODHA merupakan pendosa yang melanggar aturan Tuhan lewat perbuatan immoral.

Penolakan masyarakat bisa dilihat dari sikap sinis, diskriminasi, isolasi sosial, pelecahan secara lisan, dan pelayanan kesehatan yang lambat yang seluruhnya timbul akibat adanya stigma negatif masyarakat. Akibat lanjutannya, ODHA di Indonesia tidak tercatat dengan baik karena para penderita enggan melaporkan kondisi mereka dan lebih nyaman menyembunyikan status penyakit mereka.

Jenazah penderita HIV/AIDS ketika dimakamkan juga dibungkus plastik dan dimasukkan ke dalam peti. Semua peralatan bekas pasien HIV/AIDS dibakar dan masyarakat mengucilkan keluarga mereka (R. Maharani, 2014, Sarikusuma, 2012). Stigma negatif masyarakat muncul karena pengetahuan yang rendah, persepsi negatif, dan tidak pernah berinteraksi dengan ODHA serta kurangnya pengetahuan tentang HIV/AIDS. Akibatnya, penyebaran AIDS tidak terdeteksi (F. Maharani, 2017, Raksanagara, Afriandi, \& Kunci, 2013).

Selain stigma negatif yang diberikan masyarakat pada ODHA, 60\% ODHA mengalami depresi, yaitu kesedihan sangat hebat dan bertahan dalam jangka waktu yang cukup lama (Yayasan Spiritia, 2014). Data menunjukkan, perempuan yang terjangkit HIV AIDS memiliki kemungkinan mengalami depresi dua kali lipat dibandingkan laki-laki. 
Warta Ikatan Sarjana Komunikasi Indonesia e-ISSN: 2686-0724 - p-ISSN: 0853-4470 - Vol. 3, No. 01 (2020), pp. 45-52

Angka depresi pada penderita HIV/AIDS sebanyak 55,8\% dengan pembagian depresi ringan $25,6 \%$, depresi sedang $11,6 \%$, depresi berat $4,7 \%$, dan depresi sangat berat $14 \%$. Depresi terbanyak ditemukan pada usia 20-39 tahun, sebanyak 83,3\% (Yaunin, Afriani, dan Maulidya, 2014). Sindrom depresi pada pasien ODHA ada pada kategori depresi sedang yaitu 22,7\%, kemudian sindrom depresi berat 33,1\% (Saragih, 2008). Lebih jauh penelitian menunjukkan, terdapat hubungan signifikan antara keluarga dan kerabat dengan tingkat depresi penderita HIV AIDS (Kusuma, 2011, Ismayadi, 2016).

Menghadapi stigma negatif dari masyarakat, mau tidak mau para penderita ODHA menutupi kondisi mereka jika ingin diterima oleh masyarakat. Erving Goffman melalui pendekatan Dramaturgi menyatakan, tujuan manusia berinteraksi adalah ingin mengelola pesan sesuai harapannya yang nanti akan dilihat dari feedback orang lain kepadanya.

Dramaturgi memandang manusia sebagai aktor yang tengah memainkan peran di sebuah panggung dan aksi dipandang sebagai sebuah perform dengan penggunaan simbol sebagai upaya untuk menghadirkan kisah atau cerita (Suneki \& Haryono, 20170, Hasna Sarikusuma, Nur Hasanah, 2012). Menjalani kehidupan sebagai ODHA sungguh berat. Mereka dipaksa menampilkan kondisi yang tidak sebenarnya, menutupi apa yang terjadi hanya untuk mengelola kesan sebagaimana yang diharapkan oleh masyarakat.

Para ODHA mengelola kesan mereka sedemikian rupa bukan lagi sebatas agar tidak dikucilkan atau agar tidak mempermalukan keluarga. Penelitian ini mencoba melihat lebih jauh pada tahap selanjutnya bagi para ODHA yang telah menerima kenyataan mereka positif mengidap HIV AIDS.

Tujuan penelitian ini untuk melihat bagaimana para ODHA mengelola kesan di panggung depan dan panggung belakang sehingga mereka bisa diterima dan berbaur dengan masyarakat tanpa beban atau ketakutan atas kondisi mereka yang sebenarnya. Penelitian ini ingin melihat bagaimana ODHA menjalani kehidupan mereka dengan kesan yang mereka kelola sehingga masyarakat nantinya bisa mengubah persepsi mereka secara perlahan sehingga tidak lagi mendiskriminasi penderita HIV AIDS.

Diskriminasi berujung depresi bagi penderita ODHA perlahan mulai bisa diatasi yang dapat dilihat dengan munculnya vloger seperti@acepgates. Mereka dengan gamblang memproklamirkan diri sebagai penderita HIV AIDS dan berhasil menarik simpati masyarakat. Konten-kontennya sarat dengan informasi dan pengalaman mengenai pengobatan serta kegiatan sehari-hari. Vlog @acepgates mendapat $76,4 \mathrm{~K}$ subscribers dan lebih dari $3 \mathrm{M}$ viewers.

Kata kunci dalam dramaturgi adalah show, impression, front region, back stage, setting, penampilan dan gaya. Proporsinya (Widodo, 2010: 178): (1) interaksi sosial yang terjadi di panggung depan tidak jauh berbeda dari sebuah pertunjukan teater. Aktor akan menampilkan sisi terbaik dari dirinya karena ia sadar tengah menjadi pusat perhatian; (2) dalam panggung belakang, aktor biasanya melepaskan atribut-atribut yang digunakan di panggung depan sembari menyiapkan diri untuk pertunjukan selanjutnya. Di sini aktor bisa menjadi dirinya sendiri; (3) dalam setiap pertunjukan, aktor bisa menyajikan pertunjukan yang dianggap menarik bagi orang lain, namun kesan si pelaku bisa berbedabeda; (4) Ada panggung depan (front stage) dan panggung belakang (back stage).

Panggung depan adalah penampilan individu yang secara teratur berfungsi di dalam mode umum, tetap mendefinisikan situasi yang menyaksikan penampilan itu. Di dalamnya termasuk setting dan personal front yang selanjutnya dibagi menjadi penampilan (impression) dan gaya atau manner (Suneki \& Haryono, 2017).

Dengan demikian, penelitian ini menganalisa bagaimana para penderita ODHA di Kota Pekanbaru dengan masyarakatnya sangat kuat memegang budaya Melayu yang identik dengan nilai-nilai agama Islam memandang stigma negatif mengidap HIV-AIDS. Rumusan penelitiannya adalah bagaimana ODHA mengelola kesan yang ditampilkan melalui panggung depan dan panggung belakangnya.

\section{KERANGKA TEORI}

Kajian Dramaturgi dipopulerkan oleh Erving Goffman. Istilah ini dituangkan dalam buku berjudul The Presentation of self in Everyday Life tahun 1959. Goffman memperkenalkan konsep dramaturgi yang bersifat penampilan teateris, yakni memusatkan perhatian atas kehidupan sosial sebagai serangkaian pertunjukan drama yang mirip dengan pertunjukan di panggung, ada aktor dan penonton.

Tugas aktor hanya mempersiapkan diri dengan berbagai atribut pendukung dari peran yang ia mainkan, sedangkan bagaimana makna tercipta, masyarakat atau penonton yang memberi interpretasi. Individu tidak lagi bebas menentukan makna tetapi konteks yang lebih luas menentukan makna (dalam 
hal ini adalah penonton dari sang aktor). Karya melukiskan bahwa manusia sebagai manipulator simbol yang hidup di dunia simbol (Suneki \& Haryono, 2012).

Pemikiran awal teori ini bermula pada ketegangan yang terjadi antara " $P$ " dan " $m e$ " dengan konsep " $P$ " merujuk pada apa adanya sedangkan konsep " $m e$ " merujuk pada diri orang lain. Perbedaan antara harapan orang terhadap apa yang mesti kita harapkan merupakan awal mula ketegangan tersebut. Fokus pendekatan dramaturgi terletak pada bagaimana cara orang bertindak. Dramaturgi di sini menekankan dimensi ekspresif aktivitas manusia yang menghasilkan perilaku dramatis dari manusia (Suneki \& Haryono, 2012).

Goffman menginterpretasikan konsep "diri" dari Mead. Pengembangan diri sebagai konsep, oleh Goffman tidak terlepas dari pengaruh gagasan Cooley tentang "the looking glass self”. Gagasan diri ini terdiri dari tiga komponen. Pertama, kita mengembangkan bagaimana kita tampil bagi orang lain; kedua, kita membayangkan bagimana penilaian mereka atas penampilan kita; ketiga, kita mengembangkan sejenis perasaan diri, seperti kebanggaan atau malu, sebagai akibat membayangkan penilaian orang lain tersebut.

Fokus dramaturgis bukan konsep diri yang dibawa sang aktor dari situasi ke situasi lainnya atau keseluruhan jumlah pengalaman individu, melainkan diri yang tersituasikan secara sosial yang berkembang dan mengatur interaksi-interaksi spesifik. Menurut Goffman, diri adalah "suatu hasil kerjasama" (collaborative manufacture) yang harus diproduksi baru dalam setiap peristiwa interaksi sosial. Presentasi-diri seperti yang ditunjukan Goffman, bertujuan memproduksi definisi situasi dan identitas sosial bagi para aktor, dan definisi situasi tersebut mempengaruhi ragam interaksi yang layak dan tidak layak bagi para aktor dalam situasi yang ada.

Goffman mengasumsikan, ketika orang-orang berinteraksi, mereka ingin menyajikan suatu gambaran diri yang akan diterima orang lain. Ia menyebut upaya itu sebagai "pengelolaan pesan" (impression management), yaitu teknik-teknik yang digunakan aktor untuk memupuk kesan-kesan tertentu dalam situasi tertentu untuk mencapai tujuan tertentu (Musta'in, 2010).

Menurut Goffman kehidupan sosial itu dibagi menjadi "wilayah depan" (front region) dan "wilayah belakang" (back region). Wilayah depan merujuk kepada peristiwa sosial yang menunjukkan bahwa individu bergaya atau menampilkan peran formalnya. Mereka sedang memainkan perannya di atas panggung sandiwara di hadapan khalayak penonton. Sebaliknya wilayah belakang merujuk kepada tempat dan peristiwa yang memungkinkannya mempersiapkan perannya di wilayah depan.

Wilayah depan ibarat panggung sandiwara bagian depan (front stage) yang ditonton khalayak penonton, sedang wilayah belakang ibarat panggung sandiwara bagian belakang (back stage) atau kamar rias tempat pemain sandiwara bersantai, mempersiapkan diri, atau berlatih untuk memainkan perannya di panggung depan (Musta'in, 2010, Mulyana, 2007a).

\section{METODE PENELITIAN}

Penelitian ini menggunakan metode penelitian kualitatif dengan pendekatan fenomenologi. Metode penelitian kualitatif deskriftif adalah suatu metode dalam meneliti status kelompok manusia, suatu objek, satu set kondisi, suatu pemikiran ataupun suatu kelas peristiwa pada masa sekarang (Moleong, 2017, Sugiyono, 2012).

Peneliti menggunakan pendekatan fenomenologi untuk mengetahui presentasi diri yang ditampilkan ODHIV kepada masyarakat atau lingkungan sosialnya. Peneliti melihat kesadaran dari pengalaman (awareness of experience), yaitu sudut pandang pengalaman dari orang pertama. Jadi dengan menggunakan pendekatan fenomenologi, peneliti meneliti ODHIV yang menyatakan dirinya ODHIV sebagai key informan, dan berusaha menggali pengelolaan kesan yang ditampilkan.

Tabel 2. Daftar Informan

\begin{tabular}{cllll}
\hline No & Inisial & Umur & Lama terkena HIV & Pekerjaan \\
\hline 1 & BR & 34 tahun & 6 tahun (key informan) & Guru olahraga \\
2 & SS & 19 tahun & 4 bulan & Mahasiswa \\
3 & RD & 27 tahum & 5 tahun & Karyawan \\
4 & TT & 34 tahun & 10 tahun & Ibu rumah tangga \\
\hline
\end{tabular}


Warta Ikatan Sarjana Komunikasi Indonesia e-ISSN: 2686-0724 - p-ISSN: 0853-4470 - Vol. 3, No. 01 (2020), pp. 45-52

Subjek penelitian merupakan informan yang menjadi sumber dalam rangkaian penelitian. Informan adalah orang pada latar penelitian yang dimanfaatkan untuk memberi informasi tentang situasi dan kondisi latar penelitian (Moleong, 2017). Pemilihan subjek penelitian menggunakan teknik Snowball yang memungkinkan peneliti melihat pihak luar menjadi salah satu informan kunci (key Informan).

Teknik pengumpulan data dilakukan melalui observasi dan wawancara mendalam. Observasi adalah proses pengumpulan data dengan cara peneliti turun langsung ke lapangan untuk mengamati apa yang terjadi di lapangan. Teknik observasi memungkinkan peneliti melihat, mencatat dan terlibat langsung dengan aktivitas informan. Hal ini memungkinkan peneliti mendapatkan data yang sebenarnya dan pada suatu titik peneliti mampu melihat dan mengetahui makna dari perilaku yang tampak (Sugiyono, 2012). Saat melaksanakan observasi, peneliti melakukan pendekatan secara personal dan mengaku pada para informan bahwa peneliti memiliki saudara yang juga mengidap HIV AIDS sehingga informan mendapat kebebasan untuk membuka diri karena tidak merasa dihakimi oleh Peneliti.

Wawancara digunakan sebagai teknik pengumpulan data melalui penyampaian pertanyaan yang sifatnya umum hingga rinci dengan tujuan sebagai pendahuluan atau untuk menemukan data yang lebih mendalam. Teknik pengumpulan data ini berdasarkan dari laporan tentang diri atau self-report, atau setidak-tidaknya pada pengetahuan atau keyakinan pribadi (Sugiyono, 2012).

\section{HASIL PENELITIAN}

Data yang dikumpulkan selama penelitian kemudian direduksi berdasarkan pertanyaan wawancara. Hasil penelitian memaparkan jawaban-jawaban informan serta data dari hasil observasi penelitian yang berguna untuk dianalisa secara akademis sesuai dengan kebutuhan penelitian (Moleong, 2017, Sugiyono, 2012).

Tabel 3. Profil Informan

\begin{tabular}{|c|c|c|}
\hline 1 & Informan BR (L) & $\begin{array}{l}\text { BR pria berusia } 34 \text { tahun, berasal dari Bandung, anak ke } 6 \text { dari } 7 \text { bersudara. } \\
\text { Peneliti kenal BR dari Lembaga Swadaya Masyarakat Lancang Kuning } \\
\text { Support Group. BR telah bergabung di yayasan itu lebih dari } 5 \text { tahun. BR } \\
\text { mengidap HIV } 6 \text { tahun, terinfeksi HIV melalui hubungan sex dengan mantan } \\
\text { kekasihnya. }\end{array}$ \\
\hline 2 & Informan SS (P) & $\begin{array}{l}\text { SS, mahasiswa semester dua di Pekanbaru, berusia } 19 \text { tahun. SS tinggal } \\
\text { bersama orangtua dan satu orang adik perempuannya. SS gadis berparas } \\
\text { cantik. SS terkena HIV karena melakukan hubungan sex dengan mantan } \\
\text { kekasihnya. }\end{array}$ \\
\hline 3 & Informan RD & $\begin{array}{l}\text { RD merupakan teman BR. Pribadinya humoris, berbadan tinggi dan berpostur } \\
\text { kurus. RD berasal dari Sumatera Barat, merantau ke Pekanbaru dan tinggal } \\
\text { bersama saudara perempuannya. RD berusia } 27 \text { tahun, bekerja di salah satu } \\
\text { perusahaan swasta. Sudah tinggal di Pekanbaru } 7 \text { tahun dan terinfeksi HIV } \\
\text { sejak } 5 \text { tahun silam. Penyebabnya, hubungan seksual dengan mantan } \\
\text { kekasihnya. }\end{array}$ \\
\hline 4 & Informan TT & $\begin{array}{l}\text { TT, janda dengan } 2 \text { orang anak. TT tinggal sendirian di rumah kontrakannya. } \\
\text { Anak pertamanya tinggal bersama neneknya dan anak kedua tinggal bersama } \\
\text { mantan suami keduanya. TT dua kali menikah. Dari suami pertama } \\
\text { mempunyai } 1 \text { orang anak dan dari suami kedua memiliki anak kembar tetapi } \\
1 \text { dari dari anak kembarnya itu sudah meninggal karena virus HIV. Saat ini } \\
\text { anak pertamanya berusia } 11 \text { tahun dan anak keduanya } 4 \text { tahun. TT sudah } 10 \\
\text { tahun terinfeksi HIV yang dia peroleh dari mantan suami pertamanya seorang } \\
\text { pengguna narkoba jenis jarum suntik. }\end{array}$ \\
\hline
\end{tabular}

\section{Front Stage ODHA}

Panggung depan (Front stage) Orang dengan HIV AIDS di Kota Pekanbaru terdiri dari dua bagian, yaitu setting (pemandangan fisik) dan front personal (penampilan dan gaya). Panggung depan ODHA dapat dilihat dalam lingkungan keluarga, kampus dan tempat kerja. Mereka selalu menjaga sikap sebaik mungkin, dan terlihat lebih ceria. Mereka menghindari pembahasan mengenai kesehatan apabila sedang berkumpul dengan keluarga. Apabila pergi berobat ke rumah sakit, mereka akan memberikan berbagai alasan agar tidak dicurigai dan ditanyai lebih lanjut.

Beberapa alasan yang paling sering dikemukakan informan antara lain: (1) mengelak membicarakan masalah kesehatan. Topik kesehatan adalah hal yang sensitif bagi ODHA. Ketika 
Warta Ikatan Sarjana Komunikasi Indonesia e-ISSN: 2686-0724 - p-ISSN: 0853-4470 - Vol. 3, No. 01 (2020), pp. 45-52 mengobrol dengan orang lain, ODHA mengelak membahas soal kesehatan, karena mereka tidak sehat jasmani; (2) berbohong agar bisa pergi ke Rumah Sakit. ODHA harus minum obat untuk memperlambat kerja virus agar pengidap dapat berthan hidup. Mereka harus pergi ke rumah sakit karena obat hanya tersedia di rumah sakit.

RD merupakan informan yang bekerja di bagian gudang di salah satu perusahaan swasta di Pekanbaru. RD berbohong untuk alasan pergi ke Rumah Sakit. Alasan-alasan klise seperti "refreshing", "jalan-jalan", "ada urusan penting", "saudara menikah" sering dia lontarkan agar mendapat izin dari kantornya. Tidak hanya RD, informan TT juga kerap berbohong ketika harus pergi ke Rumah Sakit.

Manner (gaya dan sikap) yang ingin dibangun oleh ODHA adalah sosok yang menjaga kesehatan, menjaga pola makan dan pola tidur. Saat bepergian mereka berpakaian rapi menggunakan kemeja untuk pria dan wanita menggunakan pakaian tertutup serta berjilbab. Saat bepergian dan di rumah mereka menggunakan masker. Saat bertemu orang baru mereka enggan bersalaman. Mereka juga menjaga jarak sosial dengan orang lain. Mereka sudah membentengi dan membedakan diri mereka dengan orang lain.

Beberapa upaya yang ditempuh ODHA agar dapat diterima dan berinteraksi dengan masyarakat adalah: (1) menjaga kesehatan. Hidup sehat adalah point penting bagi ODHA agar tidak memperburuk keadaan. Mereka tidak boleh memakan makanan mentah ataupun setengah matang. Menjaga pola hidup sehat, tidak begadang dan rajin berolahraga; (2) berperilaku lebih religious. Berdasarkan hasil observasi dan wawancara dengan semua informan, mereka semakin mendekatkan diri kepada Tuhan dan semakin taat beribadah.

Religiusitas mereka merupakan bentuk penyerahan diri kepada Tuhan, dan pasrah atas kondisi yang dialami dengan memperbaiki sikap dan kembali ke jalan yang lebih baik lagi: (3) enggan bersalaman. Berjabat tangan merupakan salah satu ciri khas budaya Indonesia. Berbeda dengan ODHA, mereka enggan bersalaman. Peneliti mengamati, beberapa kali ketika ODHA bertemu dengan orang lain namun sekali tidak bersalaman. Ketika peneliti menemui RD saat bermain bulutangkis bersama teman teman kelompoknya, peneliti tidak ada yang menyapa apalagi berjabat tangan; (4) menjaga jarak sosial dengan orang lain yang bukan ODHA.

Beberapa kali peneliti berkunjung ke Lembaga Swadaya Masyarakat, tempat berkumpulnya ODHA. Peneliti melihat ODHIV tidak mau menyapa atau sekedar mengobrol sama orang baru. Peneliti harus mengajak ngobrol agar ODHA mereka mau berbincang,

Appereance (penampilan) merupakan atribut yang mereka gunakan untuk mendukung penampilan dalam memainkan peran, diantaranya: (1) penampilan mereka rapi dan bersih, karena ODHA harus menjaga kebersihan dan kesehatan agar tetap fit dan segar, sehingga mereka akan lebih percaya diri. Untuk perempuan mengenakan jilbab dan baju tertutup, dan untuk laki-laki mengenakan kemeja lengan panjang dan jaket; (2) mengenakan masker agar ketika bepergian. Saat batuk mereka selalu menggunakan masker baik di rumah maupun di luar. Hal ini disebabkan ODHIV gampang terserang TBC.

\section{Back Stage ODHA}

Wilayah belakang (Back Region) adalah tempat bagi individu mempersiapkan perannya di wilayah depan yang bisa juga disebut back stage (panggung belakang). Stage itu berfungsi sebagai kamar rias, tempat mempersiapkan diri atau berlatih untuk memainkan perannya di panggung depan. Di panggung ini dilakukan semua kegiatan tersembunyi untuk melengkapi keberhasilan akting dan penampilan diri yang ada pada panggung depan (Mulyana, 2007b).

Kehidupan panggung belakang ODHA menunjukkan mereka lebih senang bertemu dengan teman sesama ODHA, sebab mereka merasa lebih nyaman untuk berbincang dan berinterakasi. Di sini mungkin akan terdapat perbedaan yang ditampilkan ODHA ketika bersosialisasi dengan teman teman sesame ODHA seperti dari peran, sikap, perilaku, mimik wajah dan cara bertutur kata.

Berikut Setting (tempat): (1) Kumpul dengan Kelompok Dukungan Sebaya (KDS). Perbedaan sifat dari ODHA kelihatan saat mereka berkumpul KDS yang merupakan tempat ODHA berbagi cerita sesama ODHA. Sifat ODHA terkesan tertutup saat bertemu dengan peneliti. Namun sifat itu berubah ketika bertemu dengan teman di KDS.

Hasil observasi dari peneliti melihat ODHA merasa senang dan wajah mereka berseri-seri ketika berkumpul dengan sesama ODHA di KDS. Ketika berkumpul bersama, mereka tidak menutup diri dan dapat membicarakan kehidupan pribadi; (2) lebih senang menyendiri di dalam kamar ketika saat sedang 
Warta Ikatan Sarjana Komunikasi Indonesia e-ISSN: 2686-0724 - p-ISSN: 0853-4470 - Vol. 3, No. 01 (2020), pp. 45-52

berada di rumah. Hal ini karena ODHA tidak bisa bercerita kepada orang lain mengenai penyakit yang mereka idap sehingga mereka harus dipendam sendiri.

Untuk manner yang ditampilkan ODHA di panggung belakang adalah sebagai berikut: pertama, di panggung belakang, ODHA bersikap lebih santai dan berperilaku bebas bersama sesama teman. Mereka bisa mengekspresikan diri yang sebenarnya tanpa ada yang harus ditutupi. Kedua, saat bertemu dengan teman Dukungan Sebaya mereka akan bercerita masalah pribadi yang dialaminya. KDS merupakan tempat mencurahkan semua isi hatinya karena hanya teman sesama ODHA yang mengerti kondisi mereka.

Ketiga, meminum obat Antiretroviral (Arv) saat sendiri. Fungsi obat Arv untuk memperlambat perkembangan HIV bagi ODHA, sehingga meminum Arv secara rutin adalah keharusan bagi ODHA. ODHA menyembunyikan identitasnya saat minum obat secara diam-diam. Salah seorang informan yang peneliti temui menggunakan alarm sebagai tanda pengingat waktu meminum obat. ODHA juga mengelabui orang lain ketika melihat mereka meminum obat dengan mengatakan obat yang mereka minum adalah obat biasa seperti flu, pilek dan lain-lain. Mereka lebih nyaman saat meminum obat Arv dalam posisi seorang diri.

Keempat, melaksanakan medical check-up menjadi keharusan bagi ODHA agar mengetahui jumlah virus di dalam tubuhnya. Jumlah virus dalam ODHA akan mempengaruhi penularan virus itu. Semakin sedikit jumlah virus, semakin kecil kemungkinan untuk menularkannya. Informan yang ditemui meminum obat Arv dengan jumlah yang berbeda-beda. Informan SS, misalanya, meminum Arv sebutir sekali sehari. Kelima, mereka bersikap terbuka dan lebih leluasa saat bertemu dengan sesama ODHA. saat bertemu mereka tidak ragu untuk bertanya mengenai apapun tentang HIV secara spontan kepada KDS. Keenam, mereka akan merasa lebih bahagia dan bersemangat jika berkumpul bersama teman sesama ODHA, karena merasa tidak sendirian melawan penyakit itu. Ketujuh, berdasarkan hasil observasi di lapangan, setelah beberapa kali bertemu ODHA di tempat dukungan sebaya, ODHA pria berpenampilan feminim saat berbicara dan gerak tubuhnya seperti perempuan (waria).

Ketika peneliti mendengar pembicaraan mereka, sering kali yang dibicarakan adalah teman-teman mereka yang juga waria. Ketika mereka memanggil temannya, intonasi suaranya melengking dan cukup keras. Saat sesama mereka berbicara, cenderung gemulai dan bermanja-manjaan, dan saling godamenggoda. Sementara itu untuk Appereance (penampilan), mereka terlihat rapi dan bersih. Pria mengenakan kaos atau kemeja lengan paanjang dan wanita mengenakan jilbab. Mereka cenderung menyukai warna-warna yang soft dan gelap, tidak terlalu mencolok dilihat.

Mereka merasa nyaman bila berada di sekeliling orang-orang yang sama dan senasib, sehingga merasa bebas mencurahkan masalah yang berkaitan dengan HIV tanpa takut dinilai negatif. Segala permasalahan kehidupan sehari-hari mereka ceritakan kepada teman teman sesama ODHA. Penampilan ketika berada di panggung belakang tidak ada bedanya dengan orang sehat lainnya. Di panggung belakang mereka bisa dengan bebas minum obat Arv tanpa ada kecurigaan dari orang lain.

Goffman mengasumsikan ketika orang-orang berinteraksi, mereka ingin menyajikan suatu gambaran diri yang akan diterima orang lain. Ia menyebut upaya itu sebagai "pengelolaan pesan" (impression management), yaitu teknik-teknik yang digunakan aktor untuk memupuk kesan-kesan tertentu, dalam situasi tertentu, untuk mencapai tujuan tertentu.

Menurut Goffman kebanyakan atribut atau aktivitas manusia digunakan untuk presentasi diri, termasuk busana yang dipakai, tempat tinggal, rumah yang dihuni, cara melengkapinya (furniture dan perabotan rumah), cara berjalan dan berbicara, pekerjaan yang dilakukan dan cara menghabiskan waktu luang (Mulyana, 2007b).

Presentasi diri orang dengan HIV-AIDS (ODHA) di kota Pekanbaru, Riau, secara lengkap dapat dilihat pada Diagram 1. 
Warta Ikatan Sarjana Komunikasi Indonesia e-ISSN: 2686-0724 - p-ISSN: 0853-4470 - Vol. 3, No. 01 (2020), pp. 45-52

Presentasi diri Orang dengan HIV (ODHA) di Kota Pekanbaru

Front Stage

\section{Setting (tempat)}

1. Di rumah, tempat kerja atau kampus. Mengelak saat membahas topik pembicaraan tentang kesehatan

2. Berbohong agar dapat pergi ke rumah sakit

\section{Manner (gaya dan sikap)}

1. Enggan bersalaman

2. Lebih religius

3. Bersikap dingin dan membatasi diri pada orang bukan ODHA

4. ODHA sangat menjaga kesehatan dan pola hidup

5. Tidak menawarkan makanan kepada orang lain

\section{Appreance (penampilan)}

1. Berpenampilan rapi dan tertutup. Saat bepergian menggunakan baju lengan panjang dan perempuan menggunakan jilbab

2. Menggunakan masker saat bepergian dan saat dalam keadaan sakit meskipun sedang di rumah.

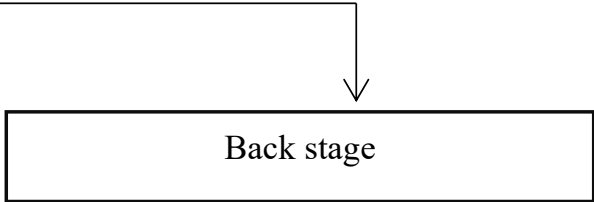

\section{Setting (tempat)}

1. Kumpul dengan kelompok dukungan sebaya

2. Lebih senang menyendiri di dalam kamar

\section{Manner (gaya dan sikap)}

1. Pria cenderung feminim

2. Ekspresi lebih santai dan bersikap bebas

3. Terbuka mengenai permasalahan pribadi

4. Meminum obat Arv saat sendirian

5. Check up ke rumah sakit sendirian

6. Lebih terbuka dan bersifat leluasa saat beretemu dengan sesama ODHA

7. Merasa lebih bahagia dan bersemangat jika kumpul bersama teman sesama ODHA,

\section{Appreance (penampilan)}

Menggunakan pakaian yang rapi, dengan baju lengan panjang. Mereka cenderung mengenakan pakaian dengan warna gelap dan tidak mencolok. Untuk perempuan mengenakan jilbab

Diagram 1. Presentasi Diri ODHA di Kota Pekanbaru Sumber: Olahan Peneliti, 2019 
Warta Ikatan Sarjana Komunikasi Indonesia e-ISSN: 2686-0724 - p-ISSN: 0853-4470 - Vol. 3, No. 01 (2020), pp. 45-52

\section{KESIMPULAN}

Panggung depan (front stage) orang dengan HIV-AIDS (ODHA) saat berada di rumah, kampus atau tempat kerja mereka mengelak membicarakan masalah kesehatan, berbohong untuk pergi ke rumah sakit, enggan bersalaman, memiliki sikap spiritual serta bersikap dingin terhadap orang lain yang bukan ODHA. Mereka juga sangat menjaga kesehatan, dan tidak menawarkan makanan kepada orang lain. Penampilan mereka rapi dan bersih, mengenakan pakaian lengan panjang dan berjilbab bagi wanita serta selalu menggunakan masker.

Di panggung belakang (back stage), ODHA berperilaku sesuai dengan jati diri yang sebenarnya. Mereka berkumpul bersama dengan kelompok dukungan sebayanya. Bila di rumah, mereka lebih suka menyendiri di dalam kamar. Gaya dan sikap saat meminum obat Arv dilakukan saat seorang. Tampilan fisik pria ODHA cenderung feminim. Check-up ke rumah sakit dilakukan seorang diri dan merasa lebih bahagia jika kumpul bersama teman sesama ODHA. Mereka juga lebih terbuka dan bersifat leluasa ketika bertemu sesama ODHA.

\section{DAFTAR PUSTAKA}

Hasna, S., Nur Hasanah, I. H. (2012). Konsep Diri Orang dengan HIV dan AIDS (ODHA) yang Menerima Label Negatif dan Diskriminasi dari Lingkungan Sosial. Psikologia : Jurnal Pemikiran dan Penelitian Psikologia, 7(1). https://doi.org/10.32734/psikologia.v7i1.400

Ismayadi, I. (2016). Hubungan Stigma, Depresi dan Kelelahan dengan Kualitas Hidup Pasien HIV/AIDS di Klinik Veteran Medan. Idea Nursing Journal, 7(1), 1-13.

Maengkom, A. O., Kaunang, W. P. J., \& Korompis, M. D. (2017). Analisis Tindakan Pencegahan Penularan HIV/AIDS di Klinik Hohidiai Kusuri Kecamatan Tobelo Barat Kabupaten Halmahera Utara. Ikmas, 2, 3-4.

Maharani, F. (2017). Faktor -Faktor yang Berhubungan dengan Stigma terhadap Orang dengan HIV/AIDS (ODHA). Jurnal Endurance, 2(2), 158. https://doi.org/10.22216/jen.v2i2.1300

Maharani, R. (2014). Stigma dan Diskriminasi Orang dengan HIV/AIDS (ODHA) pada Pelayanan Kesehatan di Kota Pekanbaru Tahun 2014. Health Service In 2014. 2(5), 225-232.

Moleong, L. J. (2017). Metodologi Penelitian Kualitatif (Edisi Revisi). Bandung: Remaja Rosdakarya.

Mulyana, D. (2007a). Ilmu Komunikasi: Suatu Pengantar. Edisi Revisi. Bandung: Remaja Rosdakarya.

Mulyana, D. (2007b). Ilmu Komunikasi: Suatu Pengantar. Edisi Revisi. Bandung: Remaja Rosdakarya.

Musta'in. (2010). Teori Diri sebuah Tafsir Makna Simbolik. Komunika. 4(2), 269-283.

Paryati, T., Raksanagara, A. S., Afriandi, I., \& Kunci, K. (2013). Faktor-faktor yang Mempengaruhi Stigma dan Diskriminasi kepada ODHA (Orang dengan HIV/AIDS) oleh Petugas Kesehatan: Kajian Literatur. Pustaka Unpad, (38), 1-11.

Sarikusuma, H. (2012). Konsep Diri Orang dengan HIV dan AIDS ( ODHA ) yang Menerima Label Negatif dan Diskriminasi dari Lingkungan Sosial. Psikologia, 7(1), 29-40.

Shaluhiyah, Z., Musthofa, S. B., \& Widjanarko, B. (2014). Stigma Masyarakat terhadap Orang dengan HIV/AIDS. Kesmas: National Public Health Journal. 9(4), 333-339.

Sugiyono. (2012). Metode Penelitian Kuantitatif, Kualitatif dan $R \& D$. Bandung:A lfabeta.

Suneki \& Haryono. (2017). Paradigma Teori Dramaturgi Terhadap Kehidupan Sosial. Jurnal Akuntansi Aktual, 4(1), 10-21.

Suneki, \& Haryono. (2012). Paradigma Teori Dramaturgi terhadap Kehidupan Sosial. Civis.

Wahyu, S., Taufik, T., \& Ilyas, A. (2012). Konsep Diri dan Masalah yang Dialami Orang Terinfeksi HIV/AIDS. Konselor, 1(2). https://doi.org/10.24036/0201212695-0-00 